\title{
TOWARDS A MARKET IN UNMATURED TORT CLAIMS
}

\author{
Robert Cooter*
}

TORT claims arise only if possible events, such as accidents, actually happen. A pedestrian, for example, cannot sue until she is injured as a result of a driver's neghigence. The fact that the pedestrian may be injured by the driver sometime in the future conveys no current right to compensation. The term "unmatured tort claim" (UTC) refers to tort claims, like the pedestrian's, based on accidents that may occur in the future.

Current tort law generally prohibits trading in UTCs-i.e., the pedestrian cannot sell her potential claim to the driver (or the driver's insurer). ${ }^{1}$ More generally, however, trading on financial markets in contingent claims has proliferated in response to recent relaxation of restrictions. ${ }^{2}$ Suppose the legal prohibitions against UTCs were relaxed, allowing, for example, the pedestrian to sell her potential claim. If the same ingenuity that has gone into imventing new financial imstruments were brought to bear on UTCs, a brisk market might develop.

Though a market for UTCs appears foreign at first, many practical proposals for tort reform effectively adopt such a scheme. ${ }^{3}$ These proposals

* Professor of Law, University of California, Berkeley (Boalt Hall).

I am grateful to nuy research assistant, Jeff Lange, for help in revising an earhier draft, and to Cehia Ronis for preparing the manuscript. Also, Jeffrey O'Connell, Doug Leshe, Charles Goetz, Dan Rubinfeld, Steve Shavell, Pablo Spiller, Alan Schwartz, Steve Sugarinan and Tom Ulen provided useful comments. The policy aspects of a market for UTCs are explained in Cooter \& Sugarman, A Regulated Market in Unmatured Tort Claims: Tort Reforn by Contract, in New Directions in Liability Law 174 (W. Olsen ed. 1988).

1 Legal barriers to claim assignment include professional rules governing lawyers and champerty statutes in sonie states, sone of which forbid certain assignments of claims to lawyers. See Sprung v. Jaffec, 3 N.Y.2d 539, 147 N.E.2d 6, 169 N.Y.S.2d 539 (1957); N.Y. Jud. Law $\S \S 488,489$ (McKinney 1988).

2 To illustrate, futures contracts convey the right to buy or sell a good contingent upon its price falling or rising to a level specified im the contract. By trading in futures contracts, busmesses can hedge against the risk of costly price fiuctuations. Novel instruments include indexed futures in which the trigger price is a composite index of stock or commodity prices.

3 See Havighurst, Private Reform of Tort-law Dogma: Market Opportunities and Legal Obstacles, 49 Law \& Contemp. Probs. 143 (1986); O'Connell, A Nco No-Fault Contract in Lieu of Tort: Preaccident Guarantees of Post Accident Settlement Offers, 73 Calif. L. Rev. 898 (1985); O'Connell, Bargaining for Waivers of Third-Party Tort Claims: An Answer to Product Liability Woes for Eniployers and the Einployees and Suppliers, 1976 Ins. L.J. 530; O'Connell, The Interlocking Death and Rebirth of Contract and Tort, 75 Mich. L. Rev. 659 (1977); O'Connell, Transferring Injured Victims' Tort Rights to No-Fault Insurers: New Sole Remedy Approaches to Cure Liability Insurance Ills, 1977 U. Ill. L.F. 749; O'Connell, Expanding No- 
envision people giving up their rights to recover in tort in exchange for improved insurance against accidents. This Article develops a nodel of a market for UTCs that generalizes and unifies these reform proposals in light of economic theory. Based on that model, I make two general arguments. First, I suggest that the prevailing law and economics wisdom on torts, dating back to Jolin Brown's classic 1973 paper, ${ }^{4}$ which holds that full compensation of victims by injurers achieves optimality, is fundamentally incomplete. Second, I argue that contracts sloould reclaim torts rather than torts absorbing contracts, a view that resonates powerfully in Grant Gilinore's The Death of Contract.

\section{SKetch OF MARKeT FOR UTCS}

UTCs are so unfamiliar that a brief description of a inarket for their sale should precede the development of a detailed model. The current regime does not recognize a potential tort victim's claim against a potential tortfeasor until the tortious injury occurs. What is inore, the tort systein generally prohibits potential victims from selling their unmatured claims to third parties. Despite tliese restrictions, the potential victim's unmatured claim, and the potential injurer's unmatured liability, are already economically valuable. Roughly speaking, the unmatured claim is worth the probability of the tort times the dainages that will be suffered if the tort occurs.

A market for UTCs conteinplates removing the restriction against the sale of unmatured clains to third parties. More specifically, the market would - permit potential tort victims to structure sales to include or exclude whatever tort riglits they wished. For instance, a person imglit sell the right

fault Beyond Auto Insurance: Some Proposals, 59 Va. L. Rev. 749 (1973); O'Connell, Harnessing the Liability Lottery: Elective First-Party No-Fault Insurance Financed by ThirdParty Claims, 1978 Wash. U.L.Q. 693; O'Connell \& Beck, Overcoming Legal Barriers to the Transfer of Third-Party Tort Claims as a Means of Financing First-Party No-Fault Insurance, 58 Wash. U.L.Q. 55 (1979); O'Connell \& Brown, A Canadian Proposal for No-Fault Benefits Fimanced by Assignment of Tort Rights, 33 U. Toronto L.J. 434 (1983); Priest, The Current Insurance Crisis and Modern Tort Law, 96 Yale L.J. 1521 (1987); Schwartz, Proposals for Products Liability Reform: A Theoretical Synthesis, 97 Yale L.J. 353 (1988); Sugarman, Doing Away With Tort Law, 73 Calif. L. Rev. 555 (1985); Sugarman, Right and Wrong Ways of Doing Away With Commercial Air Crash Litigation: Professor Chalk's 'Market Insurance Plan' and Other No-Fault Follies, 52 J. Air. L. \& Coin. 681 (1987); Sugarman, Taking Advantage of the Torts Crisis, 48 Ohio St. L.J. 329 (1987); Sugarman, Serious Tort Law Reform, 24 San Diego L. Rev. 795 (1987).

For a review of reform proposals, see Shukatis, A Market in Personal Injury Tort Claims, 16 J. Legal Stud. 329 (1988); Smith, The Critics and the Crisis: A Reassessment of Current Conceptions of Tort Law, 72 Cornell L. Rev. 765 (1987).

4 Brown, Towards An Economic Theory of Liability, 2 J. Legal Stud. 323 (1973). 
to recover intangible losses in minor automobile accidents and retain the right to recover tangible losses. Or a person might sell the right to recover damages for medical malpractice from a particular health inamtenance organization and retain the right to recover for consumer product injuries.

Under my proposed market, anyone would be permitted to buy UTCs from willing sellers. If a third party bought a UTC and the claim subsequently matured, only the new owner could assert the tort claim agamst the tortfeasor. If that third-party owner turned out to be the tortfeasor, the sale of the UTC effectively would have settled the case before the tort was committed. Because the tortfeasor-owner will not sue himself, the purchase of the UTC forecloses any further claim based on that particular tort.

A potential victim who sold his UTCs and was subsequently mjured in a tort would either recover from his insurer, if he were imsured, or bear his own loss. Given these alternatives, potential victims might willingly sell their UTCs in two situations: first, if the victim were already insured for the injury at risk in the particular tort; and second, if the victim believed that insurance was inappropriate for that risk. ${ }^{5}$ Potential tortfeasors and their insurance comparies would want to buy UTCs to the extent that presettlement was cheaper than resolving the claim after the tort occurred. In addition, some law firms might bid for undervalued UTCs since, presumably, lawyers are well situated to pursue tort claims efficiently once they mature.

Notice that a market for UTCs would permit people to achieve by private agreement many of the goals that tort reformers seek to mipose by law. To illustrate, suppose that drivers sell some of their rights to recover for tortious automobile accidents to their own insurance company, and that their own insurance company waives these rights in exchange for payment froin the insurance companies of other drivers. This series of private agreements would create a regime of no-fault auto insurance. Similarly, suppose an employer bought the rights of employees to recover damages for pain and suffering caused by medical malpractice, and the employer waived these rights $\mathrm{m}$ exchange for a fee from a health maimtenance organization. As a result, the alleged mefficiency and waste generated by pain and suffering claims in medical malpractice cases would vanish. Moreover, a market for UTCs ouly effectuates changes im tort rights that are voluntary on the part of victims and imjurers, thus avoiding the drawback of alternative proposals that truncate the rights of tort victims by legislative fiat.

One argument agaimst uny proposal rests on. a misunderstanding of America's nineteenth century experience with UTC markets. Prior to this century, workers and consumers had broad powers to waive tort rights, and

5 See infra notes 21-24 and accompanying text. 
employers and producers possessed similar powers to disclaim liability. ${ }^{6}$ Courts, lowever, became imcreasmgly disenclianted with these waivers and disclaimers. ${ }^{7}$ The courts feared that workers and consumers liad not bargained over waiver terms that typically were buried in opaque form contracts. Additionally, though knowledgeable consumers might, in primciple, "shop" for contracts that protect the value of their tort claims, in reality high transaction costs obstruct competition. Thus einployees who were dissatisfied with the hability terms in their employment contracts conld only test the market by looking for new jobs-an obvious and formidable hurdle. Similarly, dissatisfied customers conld go to different sellers and compare the fine primt in alternative purchase agreements. So by the middle of the twentieth century, the courts had all but eliminated the consumer's power to assume the risk of tort injuries. ${ }^{8}$

Although tort rights could be waived in the nineteenth century, they conld not be sold to third parties. Prohibiting sales to third parties blocked competitive bidding and brought the usual abuses associated with monopoly-unequal power, asymmetrical information, and distorted prices. Courts responded eveutually by closing the market for UTCs. The predictable effects of closing a inarket by government order are soaring prices and limited supphes, which can be observed today in markets for tort insurance. Instead of closing the inarket, its deficiencies should have been corrected, inost notably by opening the inarket wider to curtail monopoly power.

Projecting the flaws of the nineteeuth century experience onto the proposed market for UTCs fails to consider critical differences between them. As will be explained shortly, my proposal envisions that courts will police for and invalidate those sales of UTCs that are not the product of a bargain.

6 See Friedman, Civil Wrongs: Personal Injury Law in the Late 19th Century, Am. B. Found. Res. J. 351, 370-71 (1987). Additionally, nineteenth century courts justified the legal rules that limited the hability of employers to injured workers on the ground that einployees had implicitly sold their unmatured accident claims when they signed their employment contracts. In Farwell v. Boston \& W.R.R., 45 Mass. (4 Met.) 49 (1842), for instance, Chief Justice Shaw of the Supreine Judicial Court of Massachusetts reasoned that "lie who engages in the employment of another for the performance of specified duties and services, for coinpensation, takes upon himself the natural and ordinary risks and perils incident to the performance of sucl services, and in legal presumption, the compensation is adjusted accordingly." Id. at 57.

7 For early cases which held that contract terms that shielded employers from the tort claims of workers were void as against public policy see Hughes v. Warman Steel Casting Co., 174 Cal. 556, 163 P. 885 (1917); Johnston v. Fargo, 184 N.Y. 379, 77 N.E. 388 (1906); Pittsburgh, C.C. \& St. L. Ry. v. Kinney, 95 Ohio St. 64, 115 N.E. 505 (1916). Judge Cardozo's opinion in MacPherson v. Buick Motor Co., 217 N.Y. 382, 111 N.E. 1050 (1916), sounded a similar end to waivers of tort liability for consumer goods.

8 See, e.g., Prosser, The Assault upon the Catliedral (Strict Liability to the Consumer), 69 Yale L.J. 1099 (1960) (discussing the growth of strict products liability). 
Furthermore, by permitting any third party to purchase UTCs, a significant part of the transaction costs argument falls away. That argument depended in large part on the fact that waivers and disclaimers were tied by law to larger transactions. Under the new systein, by contrast, the worker and consumer can bargain over the hability terms in their contract, or break the ties and sell tort rights to third parties. Competition will generate inore information and higher prices.

Two restrictions on the proposed inarket for UTCs are to be implemented by courts. First, potential tort victims who wish to sell their UTCs would be required to obtain adequate insurance against the risk protected by the sold tort claim. This restriction would guarantee the fulfillment of tort law's insurance goal. 9 Second, courts would require a bargain between the parties over the sale of UTCs. The bargaining requireinent, already explored extensively in the general hiterature on contracts, ${ }^{10}$ would guarantee that exchanges are voluntary. Combining the bargain requirement with a coinpetitive market would in turn assure that potential injurers who presettle claims pay an ainount approaching the expected cost of the risks they impose upon others. In so doing, the market for UTCs also assures tort law's goal of deterrence. ${ }^{11}$

A inarket for UTCs can be defended solely because it gives people more options. UTCs are no exception to the proposition that both parties benefit in a voluntary exchange. Perhaps less obviously, the inarket for UTCs may also be defended as a superior vehicle for achieving tort law's two proclaimed goals-deterrence and insurance. If a market in UTCs were estabhished along the lines proposed in this Article, potential victims would substitute cheaper first party insurance for the tort system's current third party insurance scheme. Additionally, competitive pricing of UTCs would result in appropriate deterrence of potential tortfeasors. Beeause the price of UTCs should vary aceording to the likelihood and severity of potential torts, the potential tortfeasor faced with purchasing the UTC or risking hitigation should take the optimal ainount of precaution. ${ }^{12}$

\section{The Cost of Forbidding the SALE of Tort Rights}

Why would a rational person want to sell UTCs? The present tort system creates contingent claims that amount to insurance of accident victims by

9 See infra notes $13-14$ \& 25-26 and accompanying text.

10 See Eisenberg, The Bargain Principle and Its Limits, 95 Harv. L. Rev. 741 (1982). The existence of a bargain conventionally requires offer, acceptance, and consideration, but it does not presuppose the process of bargaining.

11 See infra notes 25-29 and accompanying text.

12 See infra notes $35-41$ and accompanying text. 
injurers, commonly called third-party insurance. Were this insurance system efficient, inuch of the arguinent in favor of UTCs would vanish. But the tort insurance scheine is flawed in important respects. First, the current systein forces potential tortfeasors to insure against soine risks that potential victims themselves would not insure against. Second, the cost of providing third-party insurance is widely viewed as excessive. ${ }^{13}$ Not only does the tort systein therefore compel the purchase of insurance that tort victims would not buy, it coinpels torffeasors to pay prices that are too high.

Given these deficiencies, victims inay often prefer injurers to pay for exposure to risk before an accident, rather than waiting for coinpensation until the injury occurs. ${ }^{14}$ Section II of this Article explains that these preferences are rational by considering in detail each of the two deficiencies of the current tort system histed in the preceding paragraph.

\section{A. Inappropriate Insurance}

This Article's defense of a inarket for UTCs requires an understanding of why rational people insure aganist certain accidents and not others, and how the current tort system distorts their choices. In this part of the Article, I first define the two basic types of accidents and provide a vocabnlary that classifies accidents according to their effect on the need for wealth. Next I draw on that introduction and elaborate the reasons why rational people insure against soine types of accidents and not against others. Finally, I detail how the tort systein forces potential tortfeasors to purchase insurance for some types of accidents that rational persons would not purchase for theinselves.

\section{A Vocabulary for Accidents}

Tortious accidents may be divided into two types-those that increase the need for wealth and those that do not. An accident that increases the need for wealth injures the victim in a way that makes her value one dollar after the accident inore highly than she valued the dollar before the accident.

Accidents can increase the need for wealth in two ways. Soine accidents, by inaking access to life's activities and pleasures inore costly, necessitate extraordinary expenditures. For instance, a disabling injury might force a victim to spend $\$ 1,000$ to install an elevator im his house. After the accident, the victim will only begin to enjoy his preaccident lifestyle when he spends his one thousand and first dollar. As a result, the accident increases the

13 See infra note 27 and accompanying text.

14 See Robinson, Probabilistic Causation and Compensation for Tortious Risk, 14 J. Legal Stud. 779 (1985). 
victim's marginal value of wealth. All accidents of this type affect the need for wealth by increasing the victim's consumption needs.

Other accidents increase the need for wealth by directly destroying the victim's wealth, such as house or car, or by curtailing or destroying the victim's earning ability, either by affecting his physical dexterity or his mental agility. ${ }^{15}$ Because these accidents force victims to work harder for the same number of dollars, the postaccident victim should value each dollar more highly. As one would predict, inost people act as if money would be inore valuable to thein if they had less wealth or earning ability, as evidenced, for example, by wage replaceinent insurance and fire insurance for houses. ${ }^{16}$

I use the term "wealth impacting" to designate those accidents that increase the need for wealth, either by increasing the victim's consumption needs or by impairing earning ability. ${ }^{17}$ In contrast, some accidents reduce the well-being of a person without affecting his need for wealth. The term "wealth neutral" best describes these accidents. To illustrate, suppose that a right-handed college professor loses a finger on her left hand. Loss of a finger on a nondominant hand is painful and disfiguring. Nevertheless, such an accident does not create special consuinption needs beyond immediate inedical expenses. Therapies or prosthetics are not required under current technology, nor does the loss reduce the professor's capacity to enjoy life. Additionally, the loss does not impair the college professor's earning ability. As a result, the college professor's need for wealth does not increase beyond medical costs.

The contrast between wealth-neutral and wealth-impacting accidents can be restated in technical language. An accident that inakes someone worse off, without increasing his need for wealth, lowers total utility without affecting the inarginal utility of income, as depicted in Figure 1. Figure 1's horizontal axis indicates the victim's wealth and its vertical axis indicates the victim's utility. The particular kind of accident depicted in this figure causes the utility curve to shift down without changing its shape. ${ }^{18}$ When an accident shifts the curve down in Figure 1, its slope remains the saine at any

15 Wealth-impacting accidents may be described also in the following slightly different terms. Think of property as a person's stock of wealth and income as his flow of wealth. Under this vocabulary, an accident may imcrease the victim's need for wealth by reducing its stock and flow.

16 Another possibility, not discussed here, is that an accident reduces a person's consumption reeds. To illustrate, a connoisseur whose physician forbids her to consume alcohol may no longer need to spend large sums on fine wines. The argument that rational people will not insure against wealth neutral effects applies a fortiori to accidents that decrease consumption needs.

17 I am grateful to Jeffrey O'Connell for suggesting the term "wealth impacting."

18 See Cook \& Graham, Demand for Insurance and Protection: The Case of Irreplaceable Commodities, 91 Q.J. Econ. 143 (1977). In general, a harmful accident must cause the curve 
Figure 1: Wealth-Neutral Accident

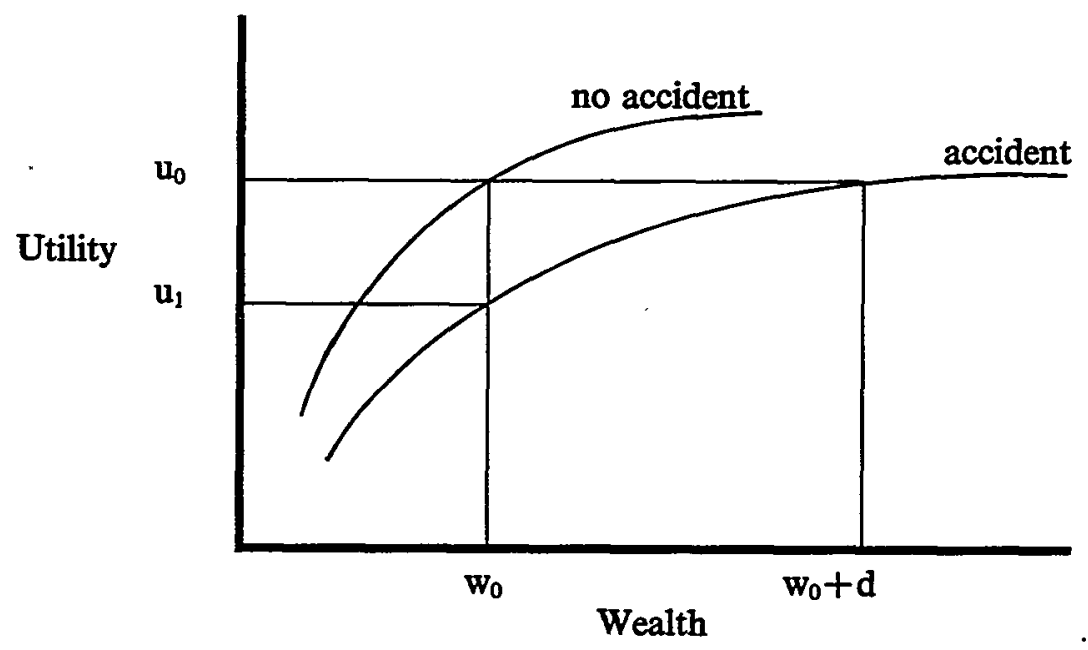

given level of wealth. ${ }^{19}$ Since the slope of the utility curve indicates the inarginal utility of inoney, and the slopes of the two curves inatch at each level of wealth, the inarginal utility of money for accidents described by Figure 1 is identical for any level of wealth, whether or not an accident occurs. To illustrate, if the victim's original level of wealth is $w_{0}$, he enjoys utility $u_{0}$ if there is no accident. An accident then causes his utility to fall to $u_{1}$. Though total utility may fall, however, the accident does not increase the victim's need for wealth because the slopes of $u_{0}$ and $u_{1}$ are the same at $w_{0}$. Accidents that do not increase the need for wealth should not be confused with accidents that do no harm. The accident depicted in Figure 1 decreases the victim's utility. The fact that the victim has no greater need for wealth after the accident does not inean that the victim does not suffer. Recall the mine-fingered college professor.

1n contrast to Figure 1, the accident depicted in Figure 2, which is wealth impacting, causes the victim's utility curve to shift horizontally instead of vertically. If the accident victim imitially has wealth $w_{0}$, he enjoys the utility level $u_{0}$ before the accident, and the accident causes utility to fall to the level $u_{1}$. The critical difference between the two graphs is that in Figure 2 the slope of the accident and nonaccident utility curves differ at given levels of

to shift, but it could twist or crimp in a variety of ways. The particular shape in Figure 1 is dictated by the need to represent a wealth-neutral accident.

19 If the utility function is written $u(w, s)$ where $s=0$ indicates no accident and $s=1$ indicates an accident, then Figure 1 depicts an accident for which $u_{1}(w, 0)=u_{1}(w, 1)$ all $w$. 
Figure 2: Wealth-Implicating Accident

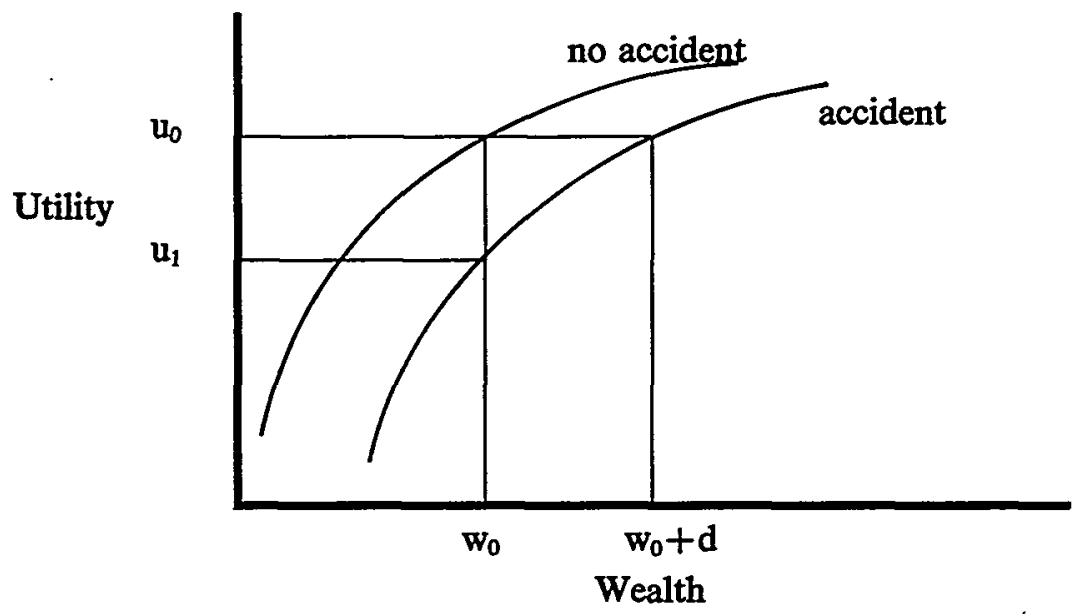

wealth. At wealth level $w_{0}$, for example, the slope of the victim's utility curve, and therefore his marginal utility of wealth, is greater if an accident occurs. $^{20}$

The two accidents depicted by Figures 1 and 2 may be termed "pure" because the fall in total utility is either captured perfectly by the change in marginal utility or not captured at all. Most accidents, however, have "mixed" effects-the fall in utility is partly captured by the change in marginal utility. Expressed graphically, most accidents shift the utility curve down and to the right. For reasons that will become clear in the next Section, the impact of a market for UTCs on mixed accidents is inost accessible if each mixed accident is viewed as the combination of two pure accidents.

\section{Why Rational People Buy Insurance}

This Section deinonstrates that an accident's effect on a victim's need for wealth determines whether he will-purchase insurance. Think of insurance as a vehicle for moving dollars in time from a potential victim before the accident to the same victim after the accident occurs. Insurance companies provide this service at a price that covers their administrative and transaction costs. Viewed in these terms, insurance aganist wealth-impacting accidents makes perfect sense. Since the victim's marginal utility of wealth increases after wealth-impacting accidents, he is willing to pay an insurance company to move dollars from one state to another.

20 In notation, $u_{1}(w, 0)<u_{1}(w, 1)$ all $w$. 
The same cannot be said of wealth-neutral accidents. Since the victim's marginal utility of wealth does not change after an accident, he is unwilling to pay an insurance company to move dollars froin one state to another. As a result, the rational person will not imsure agamst wealth-neutral effects of accidents.

\section{Compensation for Wealth-Neutral Effects}

Despite the fact that rational people insure only against wealth-impacting effects of accidents, the tort system requires tortfeasors to compensate victims for a hitany of wealth-neutral effects. The right of victims of minor torts to recover damages for pain and suffering illustrates this problem. Though the pain and suffering caused by a minor accident may be unpleasant, the victim's consumption needs are largely unaffected. To the extent that transitory pain and suffering interfere with work, the law provides for separate compensation for lost wages. Compensable pain and suffering experienced as a result of minor accidents, therefore, do not increase the victim's need for wealth.

Recalling the discussion above, a rational person would insure only against that pain and suffering that curtailed earnings. Nevertheless, the tort system compels the additional acquisition of insurance against all remaining small-accident pam and suffering. To illustrate, suppose that a careful driver severely twists his knee when his car strikes a tree. If the accident were caused by ice on the road, his own insurance pohicy wonld not permit recovery, though his teinporary disability insurance might refund his lost wages. If another driver's neghigence had caused the collision, however, the law would compel the injurer to compensate the victim for pain and suffering.

Tort law also compels compensation for intangibles similar to pain and suffering that appear to be wealth neutral, such as loss of consort and society, or alienation of affection. Defanation law pernits recovery for wealthneutral effects such as harm to personal reputation (as opposed to busmess reputation). ${ }^{21}$

Compensation for trivial property losses demonstrates the same conflict. Personal property insurance policies typically include deductibles that prevent recovery for small losses. One explanation for the deductibles stems from the relatively high cost of processing small claims. ${ }^{22}$ In order to cover these costs, insurers could charge correspondingly high preimiuns. Insured

21 Loss of business reputation may affect earning ability, but harm to personal reputation does not appear to affect consumption needs or earning ability.

22 Moral hazard is the other important explanation for deductibles. Insurance companies fear that if they covered small losses, policy holders could cheat too easily by presenting false claims. 
parties, however, almost universally opt for deductibles, in part because small property losses do not sufficiently increase wealth's marginal value to justify paying the premium. Of course, smce high processing costs also discourage victimis from bringing tort claims for trivial losses, one might argue that tort law does not compel insurance for these losses. In part this is true. But this argument fails to the extent that victimis with imdividually small losses can bring class action suits. Like compensation for intangibles, tort law's insistence on insurance for sinall property losses overinsures tort victims.

More generally, the division of tort damages into general and special damages signals whether an accident affects the marginal utility of wealth. Special damages, so designated because they must be plead specially or exphicitly, include pecuniary losses such as lost wages and medical expenses, and typically signal wealth-impacting accidents. General damages, on the other hand, mclude nonpecumary losses such as paim and suffering, emotional distress, and harm to personal reputation, and usually compensate for wealth-neutral accident effects.

The additional availability of double recovery of damages almost consciously contemplates the overinsurance of accident victims. I contend that current tort damages already compel an amount of msurance that exceeds what the rational person would purchase. When the law permits double recovery, it simply compounds the amount of mappropriate insurance provided through the tort system.

Double recovery schemes also raise obvious moral hazards since recovery in excess of the amount required for perfect compensation transforns a reluctant victim into an eager one. For this reason, insurance companies resist extending insurance beyond full coverage. Nevertheless, the collateral source rule in tort law, often results in excessive compensation since the insured victim of an accident collects froin the injurer and also the imsurance company.

Note that in some kinds of accidents perfect compensation is impossible. For imstance, virtually no parent would be imdifferent between keeping their child and losing a child and receiving compensation, regardless of the level of compensation. In formal terns, the utility levels before and after such accidents are imcomparable. ${ }^{23}$ Still, the parents' need for wealth may be compared. The death of a child does not ordinarily increase the family's

23 In notation, $u_{1}(w, 0)=u_{1}(w+f, 1)$ all $w$, where $f$ is full compensation. Also notice that in Figure 2, unlike in Figure 1, the amount of money required for perfect compensation is the same regardless of the initial level of wealth. A purely wealth-impacting accident is thus equivalent to destroying a sum of wealth that is constant with respect to initial wealth. 
need for wealth beyond immediate funeral expenses. ${ }^{24}$ That such accidents are wealth neutral explains why inost parents do not insure young children, however tragic the loss may be. The purpose of hability in tort for the death of children is not to insure the victim's family.

\section{B. Compensation Versus Insurance}

Why does tort law so consistently overshoot its insurance mark? The explanation concerns the relationship between the goals of insurance and compensation. Ideal insurance, as explained earher, covers only the effects of the accident that increase the need for wealth. Ideal coinpensation, in contrast, covers the entire loss. These two ideals are different, and the current tort system cannot achieve both. By pursuing the compensation goal with greater fidehty, tort law overshoots the insurance goal.

The belief that compensation in tort can fulfil the insurance goal belies a confusion between total and marginal utilities of tort victims. Ideal insurance covers losses that increase the victim's inarginal utility of wealth. When insurance is ideal, the marginal value of money to a person is the same regardless of whether she escapes an accident or suffers an accident and receives compensation. Ideal compensation, in contrast, restores the beneficiary to the saine level of total utility that she would have enjoyed but for the accident. When compensation is ideal, the potential victim is indifferent between escaping an accident or suffering an accident and receiving compensation.

Figures 1 and 2 help untangle the two idea. In Figure 1, damages equal to $d$ increase wealth from $w_{0}$ to $w_{0}+d$, which restore the accident victim to her original level of utility, denoted $u_{0}$. The same can be said of Figure 2. So ideal compensation requires setting damages equal to $d$ for the accidents depicted in Figures 1 and $2 . .^{25}$ Now consider insurance. The accident depicted in Figure 1 is wealth neutral so ideal insurance is nil. The accident depicted in Figure 2, in contrast, is purely wealth impacting, so ideal imsurance is fully compensatory as represented by $d$. In general, ideal insurance and ideal compensation diverge for wealth-neutral effects of accidents and converge for purely wealth-impacting effects.

I will contend that tort law should limit its function to perfect compensation by requiring damages that restore the victim's total utility whenever possible. (A different logic applies when a harm has no money equivalent, as

24 Even for these accidents, however, people must decide how much they are willing to spend to take precaution against them. Balancing the cost of precaution against the gain apparently implies at least some ability to monetize the loss.

25 The family's consumption needs decrease when there is one less child to provide for, but the loss of a child may also decease the family's future earning ability. 
with the death of a child. ${ }^{26}$ ) The insurance goal, on the other hand, should be achieved, not by law, but by markets. Toward that end, the tort law system must facilitate, not obstruct, a market for UTCs.

\section{Transaction Costs}

Many potential tort victims would, if permitted, sell UTCs and purchase additional insurance for themselves. The law, however, prohibits the transfer of the right to recover in tort before an accident occurs, and instead provides machinery for resolving disputes after they arise. In so doing, the tort system compels adherence to a particular transaction structure and insurance scheme. By closing the market for UTCs, tort law creates a regime of full insurance by third parties, when partial insurance by first parties would be preferable.

Premiuins for insurance against tort hability must include the cost of processing claims through the transaction structure prescribed by law. It follows that one reason to prefer first-party over third-party insurance is that a first-party scheine processes claims more cheaply. Tort reform advocates have long made this argument in favor of first-party insurance-a claim they support by casual empiricism and some substantial data. ${ }^{27}$ To illustrate, in cases that come to trial, the plaintiff's attorney routimely takes one-third or more of the damage award. Studies of insurance company and asbestos hitigation records indicate that tort cases yield to plaintiffs from forty-four percent to twenty-nine percent of the costs of the case. ${ }^{28}$ This suggests that so long as the transaction structure is legal rather than contractual, insurance will be unnecessarily expensive, regardless of whether the coverage is appropriate.

26 Since the loss of a child has no money equivalent, indifference cannot be the purpose of compensation. Compensation for the death of a child has altogether different purposes. One purpose is to deter injurers. I have argued elsewhere that this purpose should be used to calibrate the level of damages. For a description of the "risk-equivalent" method of computing damages see R. Cooter \& T. Ulen, Law and Economics 381-82 (1988).

27 O'Connell, Transferring Injured Victims' Tort Rights to No-Fault Insurers: New 'Sole Remedy" Appraoches to Cure Liability Insurance Ills, 1977 U. Ill. L.F. 749, 755-59, 762, 783 88; O'Connell, Harnessing the Liabihty Lottery: Elective First-Party No-Fault Insurance Financed by Third-Party Tort Claims, 1978 Wash. U.L.Q. 693, 694-95; O’Connell \& Brown, A Canadian Proposal for No-Fault Benefits Financed by Assignments of Tort Rights, $33 \mathrm{U}$. Toronto L.J. 434, 457-59 (1983); Sugarman, Serious Tort Law Reform, 24 San Diego L. Rev. 795, $843-47$ (1987).

28 Schwartz, Directions in Contemporary Products Liability Scholarship, 14 J. Legal Stud. 763 (1985). 


\section{DETERRENCE OF INJURERS}

Earher I contrasted ideal insurance with ideal compensation. This Section explores which of the two ideals provides better incentives for deterring injurers. One might think that deterrence is optimal when coinpensation corresponds to the ainount of insurance that victims would buy for theinselves. That conclusion, however, is inistaken.

Consider the preceding analysis of pain and suffering caused by a minor accident. A rational person would not purchase imsurance against minor pain and suffering. If tort dainages were set according to ideal insurance, an accident victim could not recover for pain and suffering. Although insuring against pain and suffering is irrational, avoiding it is not. Just as a rational individual avoids pain and suffering, even at substantial cost, so an efficient tort system creates incentives for people not to impose pain and suffering upon others.

Economists traditionally characterize an injurer's incentives as efficient when she internalizes all the costs she imposes upon others. Efficient deterrence, therefore, occurs when injurers are fully liable for the harm that they cause. Restated in now-familiar vocabulary, a tortfeasor who compensates for all harms restores his victim's preaccident utility-i.e., the tortfeasor must pay for both wealth-neutral and wealth-impacting accident effects. So long as tort law seeks to deter, therefore, dainages should be set according to ideal compensation, not ideal insurance.

As currently constituted, the tort systein faces a dilemina. At one extreme, the tort system can set perfectly coinpensatory dainages and create efficient incentives for precaution. ${ }^{29}$ At the other extrene, the tort system can set dainages according to perfect insurancc. Should it pursue efficient insurance or efficient deterrence, or perhaps some mixture of the two, and if a mixture, what proportion of insurance to deterrence?

The two goals of efficiency-insurance and deterrence-calmot both be achieved by a tort system unaided by inarkets. Both goals would be achieved, however, were a inarket for UTCs established. The inarket-based scheme would give potential victims the right to recover for all tortious harms that they suffer, and to sell these clains before they matured to third parties. The price that potential injurers would pay for UTCs would create efficient incentives for precaution. Potential victims who sold UTCs would in turn purchase the efficient ainount of first-party insurance. As a result, both deterrence and insurance would be efficient. This argument will be developed in the Sections that follow.

29 This proposition presupposes that various conditions are met, such as zero transaction costs of dispute resolution. As these conditions are relaxed, the proposition must be qualified. 


\section{A. Bargaining and the Market Price of UTCs}

In competitive markets, both buyers and sellers have many perfect substitutes. Tortious accidents, in contrast, have particular victims and particular mjurers who are tied together. To illustrate, I am far more likely to be injured as a result of medical malpractice by my doctor than by someone else's doctor. The efficiency gains from the market for UTCs, therefore, can be exhausted by exchange between potential victims and their likely injurers. The possibility of derivative ownership by unrelated third parties is important only as a device to assure that UTCs are not undervalued in the market because of mistakes by one of the primary parties.

Markets for UTCs are likely to be thin as a consequence, ${ }^{30}$ which introduces an essential element of bargaining. Just as perfect competition provides a benchinark for a descriptive and normative analysis of competition, so the conccpt of a "reasonable bargaim" provides a benchmark for the market for UTCs. The reasonable solution to the bargaining game between the potential injurer and the victim is closely related to the judgment that would result if the UTC were to mature and the victim sued the injurer in court. The general result is that if the parties are symmetrically situated with respect to risk bearing and transaction costs, a reasonable price for UTCs equals the judgment that would result at trial discounted by the probability of an aceident and the probability of the plaintiff's victory.

Bargaining theory helps to explain this result. A bargaining situation gives the parties an opportunity to enjoy a surplus provided that they can agree upon its distribution. Each person must receive at least his threat value-the level of utility that he can achieve on his own in the noncooperative situation-or there is no advantage to agreeing. The difference between the sum of the threat values and the value yielded by cooperation is the surplus. ${ }^{31}$ One tradition in game theory builds into the threat values all

30 The market for UTCs developed in this Article can be regarded as an application of the concept of a market for externalities, which was first proposed in Artow, The Organization of Economic Activity: Issues Pertinent to the Market Versus Non-Market Allocation, in 1 Joint Economic Comm., The Analysis and Evaluation of Public Expenditures: The PPB System, Joint Doc. No. 484, 91st Cong., 1st Sess. 47 (1969). Arrow explicitly discusses the problem of thin markets for externalities.

31 To illustrate, suppose that Adam, who lives in a small town, has a 1957 Chevy convertible in good repair. The pleasure of owning and driving the car is worth $\$ 3,000$ to Adam. Blair, who lias been coveting the car for years, inherits $\$ 5,000$ and decides to buy the car froin Adam. After inspecting the car, Blair decides that the pleasure of owning and driving the car is worth $\$ 5,000$ to her. They enter into negotiations in an attempt to agree on the sale price of the car. If they fail to agrec, Adam will enjoy utility whose monetary equivalent is $\$ 3,000$, so he must receive at least $\$ 3,000$ for the car. Blair, however, will pay at least $\$ 4,000$ for the car. There is a $\$ 1,000$ surplus to be gained from the transaction. If the parties agree to sell the car for $\$ 3,500$, the surplus will be split between them. 
the bargaining advantages that each party has against the others. ${ }^{32}$ If all advantages are included in the threat values, there is no remaining reason why one person should receive a greater proportion of the surplus than the other. Thus, a reasonable solution to the bargaining problem is for each person to receive his threat value plus an equal share of the surplus. ${ }^{33}$ This concept of a reasonable bargain has immediate application in a inarket for UTCs. If the parties fail to cooperate, a potential tort victim who is actually injured will pursue the claim to judgment. The expected benefit conferred by this right before an accident or trial equals the judgment discounted by the probability of an accident and the probability of plaintiff's victory at trial. The expected cost includes the transaction costs froin asserting the right and the risk due to inappropriate insurance. The threat position of the potential victim thus equals the probability-discounted trial judgment minus the cost of transactions and risk.

Similarly, the potential injurer stands to lose the probability-discounted judgment plus the cost of transactions and risk. The surplus from the sale of UTCs coines froin avoidimg inappropriate insurance and saving transaction costs. If the parties are similarly situated with respect to risk and transaction costs, these elements in their threat values are offsetting. Consequently, the surplus will be spht equally under the symmetry assumption when the potential injurer buys the UTC froin the potential victim at a price equal to the probability-discounted judgment. ${ }^{34}$

\section{B. Optimal Deterrence}

Though sellers of UTCs relinquish tort law's remedies before an accident occurs, the proposed inarket will continue to guard thein against aceidents by deterring potential injurers. To see why, consider that potential injurers

32 This economic language corresponds imperfectly to ordinary speech. To illustrate, a depositor at Citibank may be said to have less bargaining power than the bank. A natural conclusion to draw is that any surplus from a contract between Citibank and its depositor will be distributed disproportionately im favor of Citibank. This, however, is not a correct use of the language in the economic model. In the economic model, all of Citibank's power relative to its customers is already built into its threat value. The surplus is the value created over and above the threat values of the parties. Aecording to the economic model, the surplus, over and above the threat values, would be distributed eveuly between Citibank and its customer.

33 Economists usually proceed by developing models of rationally self-interested behavior, rather than "reasonable" behavior. This approach has generated a variety of solutions to bargaining games, but none that commands universal agreement in the profession. There is, apparently, an indeterminacy in bargaiming caused by such factors as bargaining skill and risk aversion that rationality models incorporate imperfectly. It is unnecessary, however, to await a satisfactory solution of this problem before developing an account of the market for UTCs. The concept of a reasonable bargain is adequate for the purposes of this Article.

34 The appendix illustrates this result with a numerical example. 
seek to minimize the sum of their accident-related costs, whose components are: (1) the direct cost of tort claims, those purchased while unmatured and those resolved after the tort; (2) the transaction costs associated with (1); and (3) the cost of precaution against accidents. To minimize total costs, the potential tortfeasor will purchase UTCs to the extent that presettlement of claims is cheaper than waiting until the tort occurs. The price that the potential tortfeasor pays for the UTC equals the expected value of victim's underlying tort claims (or probability of tort times probability of recovery times net probable damages).

The market for UTCs will deter dangerous behavior because the price for UTCs will reflect the probability and degree of mjury. When accidents are more frequent, the price of UTCs is relatively high. As precaution increases, the frequency and severity of accidents falls, and consequently so do UTC prices. To minimize his total accident-related costs, the potential tortfeasor will invest in precaution to the point where an additional $\$ 1$ spent on precaution reduces the price of UTCs by $\$ 1 .^{35}$

This behavior by the potential tortfeasor will, under certain conditions, minimize the accident-related costs of society as a whole. ${ }^{36}$ To illustrate, suppose that the rule of law entitles plaintiffs to recover fully for the harm caused by defendants. For the purposes of this illustration, assume perfect compensation under a rule of strict liability. ${ }^{37}$ As a result, the expected value of the judgment against defendants will equal the expected harm that they cause. Recall the demonstration in the preceding Section that, under symmetrical conditions, the probability-discounted judgment equals the market price of the UTC. The inarket price of UTCs will, consequently, equal the probability-discounted harm caused by the injurer. This price will force injurers to internalize the full cost of the risk that they impose upon others, $^{38}$ as required to achieve the socially optimal level of precaution..$^{39}$

35 I implicitly assume that the transaction costs of buying UTCs will not be affected by the probability of an accident, at least within the relevant range. This assumption is reasonable because the transaction cost of buying UTCs depends upon allocating time to the negotiation process, and the time spent negotiating a price for unmatured claims is probably unrelated to the frequency with which clains mature.

36 When claims are presettled, the social cost of accidents equals the sum of the cost of precaution, the external harm caused by accidents, and the transaction costs of the market for UTCs.

37 I imphicitly assume, as in the preceding paragraph, that transaction costs are unaffected by precaution over the relevant range of choice.

38 "Strict hability" in this context means that the injurer cannot escape liability by meeting a standard of precaution. This conception applies to dynamiting, workers compensation, or manufacturing defects in consumer products, but not so clearly to design defects in consumer products.

A similar proposition to the efficiency theoren stated in this Article could be developed for alternative hability rules, such as negligence or comparative negligence. 
I have shown that a rule holding injurers hable for the full harm that they cause will, under certain conditions, cause the bargain over UTCs to settle on a price that induces socially optimal precaution by injurers. Additionally, it follows that if blocking the market for UTCs causes the cost of accidents born by mjurers to rise above the price of UTCs, injurers will overshoot the socially optimal level of precaution. ${ }^{40}$ The ongoing failure of firms to invest in new technologies that might increase liability illustrates low overprecaution under the current regime jeopardizes imiportant social interests. ${ }^{41}$

Thougl significantly qualified by special assumptions, these observations about the UTC inarket inay still be used as the baseline for preliminary discussions of deterrence. Additionally, I regard the qualifications, which are cliaracteristic of economics, as strengths rather than weaknesses of the analysis because they make explicit the full range of interactions that a complete model must confront.

\section{Obstacles AND AdVANTAges to IMPLEMENTING A MARKET FOR UTCS}

\section{A. Obstacles}

Several objections to a market for UTCs immediately come to mind. First, potential tort victims may lack sufficient information or bargaining power to demand a price that refiects the true worth of UTCs. Second, the insurance goal might suffer if imprudent people sold their UTCs but did not purchase substitute first-party insurance. Third, instead of a brisk market developing, UTC transactions might be infrequent. And fourth, potential mjurers miglit act strategically by reducing precaution after they purchase UTCs.

\footnotetext{
39 The appendix contains a proof of this point.

40 The efficiency theorem on the market for UTCs, which is stated in the text and demonstrated in the appendix, assumes symmetry in the cost on transactions and risk by victims and injurers. Any lowering of one party's costs relative to another's, which introduces asymmetry, tips bargaining power in favor of the party with lower costs. Hence any tipping in favor of the imjurer causes the reasonable price of UTCs to fall below the expected value of the court judgment, and the injurer will have insufficient incentives for precaution. Conversely, any tipping in favor of the victim causes the reasonable price of UTCs to rise above the expected-value of the court judgment, and the injurer will have incentives for excessive precaution. Thus asymmetry in the parties' situations affects deterrence in the obvious way suggested by the theorem in the text.

41 Any increase in the liability costs associated with accidents causes injurers to take more precaution. See Polinsky \& Rubinfeld, The Welfare Inplications of Costly Litigation in the Theory of Liability, 17 J. Legal Stud. 151 (1988).
} 
As to the first and second obstacles, two simple regulatory restrictions should solve the problems that they pose. These restrictions would require that courts, at least in the early stages of the market's development, enforce only those sales of UTCs that result from a bargain and for which the seller had purchased replacement insurance.

The bargain requirement, intended to check UTC sales for less than value, extends the saine minimal protection to the market for UTCs that contract law imposes on other transactions. ${ }^{42}$ Indeed, one suspects that contract law would require the bargain element in UTC sales "contracts" in the absence of specific legislation to that affect. Thus courts would look with disfavor upon contracts which did not offer an option of waiving or retaining tort rights at an appropriate price differential. The main protection of sellers of UTCs, however, is not the law, but competition. In a brisk market for UTCs, interested classes of buyers, such as insurers and law firms, should bid up the price of undervalued UTCs until they accurately reflect the expected value of the underlying claims.

That saine idea explains why competition among secondary buyers dramatically reduces the amount of information that UTC sellers need. To illustrate, consider the purchaser of homeowner's fire imsurance. In order to make a rational decision about fire insurance, the home owner need only know that she is risk averse, that imsurance companies are risk neutral, and that the insurance market is competitive. She need not possess a keen sense about the probability that her house will burn down in order to shop effectively for insurance. Similarly, the rational seller of UTCs must only know that she values them less than buyers and that competition keeps the price in line with underlying values. If, in contrast, potential victims are permitted to sell UTCs only to their potential tortfeasors and not to third parties, the absence of competition greatly imcreases information requirements. ${ }^{43}$ According to my second restriction, UTC sales could not be enforced agaimst an uninsured accident victim, presumably on the ground that sellers cannot be trusted to advance their own interests. ${ }^{44}$ The restriction would permit an accident victim to renege on the sale of his UTC and assert his right to

42 P. Huber, Liability: The Legal Revolution and Its Consequences 14-15, 155-61 (1988).

43 The test for the enforceability of transfers of tort claims proposed in this Article applies to sales. A separate problem, not discussed here, concerns waivers of rights to recover in noncommercial contexts. For example, a parent waives the riglit to recover from the Boy Scouts as a condition for his son to go on a camping trip.

44 Suppose that I am considering waiving my tort rights against a potential injurer, but no one else is permitted to bid for the rights. The injurer offers me an advantage in exchange for the waiver-say a reduction in the price of the product. I cannot know whether the imjurer's offer is commensurate with the UTC's underlying value unless I can estimate the probability of an accident. Competition, however, provides me that assurance and reheves me of the need to estimate probabilities. 
recover in tort for any wealth-impacting effects for which he lacked a collateral source. Thus it would be incumbent upon buyers of UTCs to obtain guarantees that sellers possess adequate insurance. Without such a guarantee, the buyer might later discover that he purchased a worthless good. ${ }^{45}$ Though many might view the coerced purchase as unnecessary, it nevertheless assures satisfaction of tort law's insurance goal.

The requirement of adequate insurance, which is directed against the possibility of a seller's miprudence, would dramatically alter arguments in tort cases. Instead of information about insurance being excluded from court, as the current system dictates, ${ }^{46}$ its adequacy would become a central issue in a trial. To illustrate, if an accident victim wished to renege on the sale of her right to recover in tort for soine of the wealth-impacting effects of an accident, she would have to deinonstrate in court that her collateral sources are inadequate to cover these losses. Jurors would no longer find themselves in the situation where a decision for the defendant leaves a needy plaimtiff without compensation. Similarly, the adequate insurance requirement would relieve froin courts the pressure of scrutinizing prices in the UTC market. Witl this protection in place, underpricing of UTCs by insured sellers is not more or less a misfortune tlian underpricing a used car or boat.

The third noted problem goes to the viability of a market for UTCs. The advantages that I claim for my proposal will not materialize unless people decide to trade in UTCs. I suspect that UTCs would be actively traded for the following reason. The vigor of tlie UTC inarket will in large part depend upon the relative efficiency of presettlement and the current tort system. Since I believe that current tort law's inefficiencies are legion, I predict that, after an mitial period of experimentation in which traders learn to package UTCs and sell thein in large blocks, a market would flourislı. ${ }^{47}$ Critics can point to reasons why they believe that the market might languisli. For instance, they may claim tliat buyers will be eager to purchase UTCs from

45 Jeffrey O'Connell, using Carl Llewellyn's phrase, suggests that the insurance requirement can be understood as preserving the "minimal decencies." Llewellyn, Book Review, 52 Harv. L. Rev. 700 (1939) (reviewing Prausnitz, The Standardization of Commercial Contracts in English and Continental Law (1937)).

46 Of course, were this to occur, holders of UTCs would be entitled to return of the money they paid for the UTC on restitution grounds.

47 Efficient bargaining in a inarket for UTCs inust occur through representatives of organizations. To illustrate, enployers often provide einployees with several alternative health plans. If there were a inarket for UTCs, the einployers inight bargain with health care providers concerning the terms on which UTCs would be purchased. The health care providers inight offer reductions in preiniuns to those einployees who waived tort rights, such as their right to recover for pain and suffering caused by medieal inalpractice. Efficiency requires the aggregation of such transactions and centralized bargaining over prices, which einployers would be in a position to conduct. 
sellers who are most accident prone, whereas the eager sellers will be people who are least accident prone. ${ }^{48}$ They might also argue that if the gains from trading UTCs were so large, they already would have been realized under existing law through subrogation rights. ${ }^{49}$ Further similar objections could also be raised. ${ }^{50}$ All these objections, however, rest on empirical judgments that plausibly could be either verified or disproved by allowing a test market for UTCs. The contention that a inarket for UTCs will not flourish provides no reason for banning it.

As a practical inatter, a brisk market in contingent claims requires soine clarification of the relevant property rights. Fresh legislation that explicitly permitted UTC sales, subject to the bargain and insurance requireinents, would ideally ineet that need. Nevertheless, I hope that even without new legislation the courts begin to enforce bargained-for waivers of liability by people with adequate first-party insurance.

The fourth and more troubling criticism concerns possible misbeliavior by potential tortfeasors after they purchase UTCs. ${ }^{51}$ For exainple, suppose a firm conteinplated the possibility of buying its customers' UTCs and then relaxed quality control, thus exposing the customers to unreasonable risks. What kind of firm might do this? In the long run, the loss in profits from more costly UTCs would outweigl the increase in profits froin lower quality control. So firms with long run outlooks would not behave opportunistically. And in the very short run-say, as bankruptcy approaches-a firm

48 This poses a problem called "adverse selection."

49 Under existing law, potential victims of accidents can subrogate their rights to recover in tort to their insurance companies, and insurance companies can then agree not to sue each other. In effect, the UTC is thus sold by the victim to the injurer. Note, however, that subrogation is limited to those rights for which insurancc is written. Conversely, a market for UTCs perhaps is most promising in areas where no insurance is written, such as the right to recover damages for pain and suffering. As a result, current law severely himits the power of the subrogation approach. Furthermore, if a trial must be held to decide such issues as damages for pain and suffering, so that the whole dispute cannot be presettled, the saving in transaction costs from presettling part of the dispute is small. This fact further reduces the appeal of subrogation as a device for transferring UTCs. These considerations suggest that tort reforn should allow subrogation of tort rights to insurers that include uninsured harm such as paint and suffering.

so Another such objection concerns taxation. Coinpensation in tort is usually not taxed on the theory that it is compensation for an offsetting loss. Profits froin the sale of UTCs would be taxed. Therefore, the tax system would introduce a bias that would obstruct the market for UTCs. This objection, however, ultimately fails sincc the sale of UTCs does create real income that should be taxed, assuming that income is the tax base.

Yet another objection concerns contributory negligence. Could the market for UTCs distort a victim's precaution? It is hard to see how the problem of contributory negligence could become worse if victims must make their own private insurance arrangements, rather than recovering from imjurers.

sI I ani grateful to Pablo Spiller for stressing and clarifying this point. 
can cut quality without going to the expense of buying UTCs; such firms would not likely participate in the market for UTCs.

Still, there might be some intermediate time perspective within which strategic behavior is profitable. This might have been a powerful criticism were it not for my requireinent that victims hold adequate alternative insurance. Under this restriction, the effective duration of a UTC sale is limited by the duration of the seller's insurance. Since most insurance policies are renewed annually, the duration of the sale of a UTC would ordinarily be annual. The sale of rights to recover in tort for medical inalpractice, for instance, would ordinarily last only as long as the seller's medical and wage-replacement insurance policies. ${ }^{52}$ This annual turnover wonld severely limit the potential for opportunistic behavior by buyers of UTCs. Even so, the possibility of strategic behavior deinands systematic analysis and perhaps soine legal safeguards that cannot be discussed in this Article.

\section{B. Advantages}

Besides its principal objective of efficient insurance and deterrence, the market for UTCs offers many practical advantages that I can only mention in passing. One of the market's great advantages is its voluntary nature. Under the proposed system, everyone who wishes to rely solely on existing tort law may do so. The proposal coerces no one to sell his tort rights. Because of its voluntary character, the proposal could make some people better off than they are under current tort law without making anyone worse off. Most other reforin proposals, in contrast, contemplate stripping tort victims of some of their rights. ${ }^{53}$

An additional advantage goes to problems with insurance beyond the scope of tort law. As a method of insuring accident victims, the current tort system is full of holes. Of course these holes are imevitable because tort law conditions recovery on the accident's cause, while the desirability of insurance depends upon the accident's effect on the victim's need for wealth. Most of this Article uses that conflict to fault tort law for overinsuring by requiring compensation for wealth-neutral accidents. By the same token, however, the tort system fails to insure victims of many wealth-impactimg accidents on the ground that the accidents are not tortious-either because the injurer was not at fanlt, fault could not be proved, causation could not be proved, or the victim failed to assert a timely clainn. Strong social policy

52 A possible exception would be the sale of a right to recover damages for minor pain and suffering. Since it is irrational to buy insurance against minor pain and suffering, no insurance is adequate insurance. Thus the enforceability of the sale of these tort rights alone would not require any insurance at all.

53 J. Hamilton, Selected Generic Tort Law Changes Enacted by American States During 1986-87 (1987). 
reasons favor more comprehensive private insurance that would fully protect more victims against accidents that increase their need for wealth. In addition to its other attributes, the creation of a UTC market would stimulate private insurers to fill gaps in insurance coverage.

\section{CoNCLusion}

This Article advocates a inarket for unmatured tort claims, subject to a simple two-prong test for enforceability of contracts. First, the accident victim inust have adequate insurance against the contingency covered by the UTC. Second, the sale of the UTC must be part of a bargain. The supporting model that I present deinonstrates that a inarket for UTCs would reconcile the tension im current tort law, producing optimal deterrence of injurers and optimal insurance of victims. Though inany proposals for tort reform envision people waiving tort rights in exchange for better insurance, a market for UTCs will both achieve that end and leave current tort rights intact. 


\section{TECHNICAL APPENDIX}

This appendix derives the bargained price of UTCs by numerical exannple and demonstrates the social efficiency of that result. The numerical exainple is subsequently generalized using mathematical notation.

\section{A. Example: Bargained Price of UTCs and Optimal Deterrence}

In bargaining over the sale of UTCs, potential tort victims can threaten to retain their tort rights and assert them in the event of an accident. The value of this threat depends upon the expected payoff from trial or settlement. In the first step towards determining the reasonable price of UTCs, the expected payoff from trial or settlement must be computed.

The computation, which follows, is developed through a numerical exainple. Suppose that a person has been injured, negotiations for a settlement have failed, and a trial is about to begin. The product of the probability that the plaintiff will win and the amount that she will win is, by definition, the probability-discounted value of the judgment. ${ }^{54}$ To illustrate, if the stakes in dispute are $\$ 9,000$ and the probability of plaintiff victory is $2 / 3$, then the probability-discounted value of the judgment is $\$ 6,000$.

Assume for simplicity that a successful plaintiff must pay her attorney $\$ 3,000$ (one-third contingency fee), which covers all her hitigation costs (attorney's labor, court costs, expert witness fees, etc.), but an unsuccessful plaintiff pays nothing and these costs are absorbed by her attorney. Thus the plaintiff stands to win $\$ 6,000$ net of hitigation costs with probability $2 / 3$. The trial represents a lottery to the plaintiff in which $\$ 6,000$ will be won with probability $2 / 3$ and $\$ 0$ will be won with probability $1 / 3$. The expected value of this gamble thus equals $\$ 4,000 .^{55}$

A risk-neutral plaintiff would not be willing to sell the right to participate in this gamble for less than $\$ 4,000$. Consequently, a settlement with a riskneutral plaintiff will be impossible for less than $\$ 4,000$. A risk-averse plaintiff, in contrast, will be willing to sell the right to participate in this gamble for less than $\$ 4,000$. Assume that the risk discount is $\$ 500$. In that case, the right to participate in this gamble is worth $\$ 3,500$ to the plaintiff. This riskaverse plaintiff must be offered at least $\$ 3,500$ in order to settle.

Now repeat the saine argument for the defendant. If the defendant has the saine information as the plaintiff, they will agree that the plaintiff stands to win a $\$ 9,000$ judginent with probability $2 / 3$. Thus the probability-discounted cost of the judginent to the defendant is $\$ 6,000$. The defendant will,

54 In general, the expected value of the judgment equals the sum of the possible judgments discounted by their probabilities (the mean), which should not be confused with the judgment that is most hikely to occur (the mode).

s5 $\$ 6,000 \times(2 / 3)=\$ 4,000$. 
in addition, have to bear litigation costs. Suppose that the defendant inust pay $\$ 2,000$ in litigation costs, regardless of whether he wins or loses. Thus the defendant loses $\$ 2,000$ for certain and, in addition, the defendant participates in a gamble whose expected cost to him is an additional $\$ 6,000$. The expected cost of trial to the defendant is thus $\$ 8,000 .^{56}$

The defendant inay also be risk averse. If the defendant is risk averse, he inay be willing to pay more than $\$ 8,000$ to rid himself of this gamble. Suppose the risk premiuin is $\$ 500$. In that case, the defendant would just as soon pay $\$ 8,500$ as undergo the risk of a trial. The defendant will not, however, pay inore than $\$ 8,500$ to settle the case.

If the parties can settle the case, they will save hitigation costs, whose expected value is $\$ 2,000$ for eacli party, for a total saving of $\$ 4,000$. In addition, they will avoid a gamble whose risk premium, assuming botli parties are averse to risk, is $\$ 500$ for eacli party, for a total saving of $\$ 1,000$. Summing the savings in hitigation costs and risk premiums yields total savings of $\$ 5,000$ froin settling the case. However, negotiating a settlement costs soinething. Suppose a settleinent can be reached with hittle or no involvement of lawyers, in which case the transaction costs of settling are a fraction of the costs of trying the case, say $1 / 20$ for eacl party. ${ }^{57}$ Thus negotiation costs will be $\$ 100$ for each party. The expected value of the surplus from settling the case, rather than going to trial, will be $\$ 4,800$. $^{58}$

A reasonable bargain, in general, gives each person his threat value plus half the surplus. It is not hard to show that this will be achieved in hitigation bargaining if the defendant pays the plaintiff $\$ 6,000$ to settle the case. ${ }^{59}$ Notice that a reasonable settleinent in this example equals the probabilitydiscounted value of the judgment. This result was obtained because the parties to the dispute are symmetrically situated with respect to transaction

$56 \$ 2,000+[\$ 9,000 \times(2 / 3)]=\$ 8,000$.

57 If lawyers are extensively involved, a settlement can be quite costly. For example, the plaintiff's attorney might ask $25 \%$ for settling and $33 \%$ for trying the case.

$58 \$ 5,000-(\$ 100+\$ 100)=\$ 4,800$.

59 A rcasonable settlement is one in which the plaintiff's net payoff equals her threat value plus half the surplus from cooperation. The plaintiff's threat value equals $\$ 3,500$. The total surplus equals $\$ 4,800$, half of which equals $\$ 2,400$. Thus a reasonable settlement gives the plaimtiff a net payoff equal to $\$ 5,900$. If the defendant pays $\$ 6,000$ to settle and the plaintiff pays $\$ 100$ to his lawyer, the plaimtiff will net $\$ 5,900$. Therefore $\$ 6,000$ is a reasonable settlement from the plamtiff's viewpoint.

Similarly, a reasonable settlement gives the defendant his threat value plus half the surplus. At trial the defendant expects a net loss of $\$ 8,500$. The surplus from cooperation equals $\$ 4,800$, half of which equals $\$ 2,400$. Thus the net cost of a reasonable settlement for the defendant equals $\$ 8,500-\$ 2,400$, or $\$ 6,100$. If the defendant pays $\$ 6,000$ to the plaintiff and $\$ 100$ to his lawyer, the net cost to him will be $\$ 6,100$. Thus $\$ 6,000$ is a reasonable settlement from the defendant's viewpoint. 
costs and risk bearing. In general, if parties are symmetrically situated with respect to transaction costs and risk bearing, a reasonable settlement of their legal dispute equals the probability-discounted value of the judgment.

If bargaining over UTCs between the primary parties succeeds, disputes will be presettled. If, however, bargaining over UTCs fails, disputes will arise as contingent claims mature. Suppose that bargaining in the market for UTCs takes place in the belief that, should bargaining fail, matured clainis will be resolved through a reasonable settlement of disputes. The previous Section explained how to compute the value of a reasonable settleinent of disputes. Upon maturity of a claim, the plaintiff in the example expects to receive $\$ 6,000$ from the defendant and to pay $\$ 100$ to a lawyer. Similarly, the defendant expects to pay $\$ 6,000$ to the plaintiff as a settlement and $\$ 100$ to a lawyer. Thus the expected value of holding a inature claim equals $\$ 5,900$ to potential victims, and the expected cost equals $\$ 6,100$ to potential injurers.

Most claims, however, will never mature. The probability of an accident may be small, say $1 / 10$. The probability-discounted value of the judgment at the beginning of trial equals $2 / 3$ times $\$ 9,000$, but the probability-discounted value of the judgment before an accident occurs equals $1 / 10$ times $2 / 3$ times $\$ 9,000$, or $\$ 600$. Similarly, the probability discounted settlement cost of a possible accident that has not yet occurred equals $1 / 10$ times $\$ 100$ for each party, or $\$ 10$. Thus the expected value of holding an unmatured claim equals $\$ 590$ to potential victims, and the expected cost equals $\$ 610$ to potential imjurers.

An unmatured tort claim represents a lottery ticket that only pays off im the event of an accident. In the exainple, a potential victim who holds such a lottery ticket nets $\$ 5,900$ in the event of an accident, which happens with probability $1 / 10$, and $\$ 0$ otherwise, for an expected value of $\$ 590$. Potential victims, however, may be willing to sell their rights to participate in this lottery for less than its expected value of \$590. In particular, if the underlying accident were wealth neutral, potential victims would be willing to sell the lottery ticket for less than $\$ 590 .^{60}$

60 This conclusion can be explained in terms of insurance. If the accident in question is wealth neutral, the victim would not care to insure against it at an actuarially perfect price. When a potential victim retains a UTC, he is in effect insuring against the possibility of an accident. An actuarially-perfect premium for this insurance equals its expected value of \$590. Just as a person would not pay the actuarially perfect premium of $\$ 590$ to insure against a wealth-neutral aecident, so the person who is given such insurance in the form of a UTC would be willing to sell it for less than $\$ 590$.

Suppose, instead of the aceident being wealth neutral, it is wealth inpacting. The potential victim would want to insure fully at actuarially-perfect rates against such an accident. Suppose that the potential victim proceeds to obtain full insurance on the private market. Now that he possesses first-party insurance, the additional insurance provided by retaining the 
Suppose the potential victim's discount is $\$ 20$. Holding a claim to maturity whose expected value is $\$ 590$ will thus be worth $\$ 570$. Potential victims will be unwilling to sell their UTCs for less than $\$ 570$.

Tnrning from victims to injurers, if the potential victim retains his tort rights, the potential injurer stands to lose $\$ 6,100$ with probability $1 / 10$ and $\$ 0$ with probability $9 / 10$. If the potential injurer is risk averse, he would be willing to pay a premium above the expected cost of $\$ 610$ to get rid of this risk. If, for example, his risk premiuin were $\$ 20$, he would be willing to pay $\$ 630$ to induce solneone else to hold the risk for him.

In the preceding example, the minimum price demanded by the seller of UTCs is $\$ 570$, and the maximum price that the buyer would pay is $\$ 630$. There is, consequently, room for a mutually beneficial bargain. The difference between these prices, however, is not entirely surplus, because the market for UTCs, like other inarkets, has transaction costs. These transaction costs of inarket exchange, which are assumed to be a little less than the transaction costs of negotiating settlements and a lot less than higation costs, reduce the gain from exchange. Suppose the transaction costs are $\$ 10$ for each party who participates in the market for UTCs. Thus the surplus from inarket exchange of UTCs equals $\$ 630-\$ 570-(\$ 10 \times 2)=\$ 40$.

A reasonable price for UTCs would have the result of giving the threat value and half the surplus to the buyer and the seller. This will be achieved at a price of $\$ 600$ for the UTC. ${ }^{61}$

Notice that the reasonable price for a UTC equals the trial judgment discounted by the probability of an accident and the probability of plaintiff's victory at trial. This result was obtained because the parties to the dispute are symmetrically situated with respect to transaction costs and risk bearing. In general, if parties are symınetrically situated with respect to transaction costs and risk bearing, a reasonable price for UTCs equals the judgment at trial discounted by the probability of an accident and the probability of plaintiff's victory in litigation.

This reasonable price for UTCs will, in turn, deter the tortious behavior of potential injurers. The preceding numerical exainple assumed that the probability-discounted court judgment is $\$ 600$. Suppose the court awards

tort right is not worth its expected value to him. He would, consequently, be willing to sell it for less than $\$ 590$.

The arguments in the preceding paragraphs lead to the conclusion that potential victims will discount the value of retaining their tort rights according to the cost of first-party insurance and the effect of accidents on their need for wealth.

61 The seller must receive his threat value, $\$ 570$, plus half the surplus, $\$ 20$, which nets $\$ 590$. If he is paid $\$ 600$ and pays $\$ 10$ in transaction costs, the net is $\$ 590$ as required. Similarly, the cost to the buyer must equal his threat value, $\$ 630$, less half surplus, $\$ 20$, for a net of $\$ 610$. This will be achieved if the buyer pays $\$ 600$ for the UTC and bears $\$ 10$ in transactions costs. 
damages to successful plaintiffs that equal the actual harm that they suffer as a consequence of the accident. By assumption, therefore, $\$ 600$ is the probability-discounted external harm caused by the injurer. When the injurer pays this price for UTCs she will, consequently, internalize the full social costs of the risk to which she exposes others. Cost internalization will, in turn, provide incentives for socially-optimal precaution by the injurer, as required for socially-optimal deterrence.

\section{B. Proof: Bargained Price of UTCs and Optimal Deterrence}

The bargained price of UTCs can be computed recursively. Let $\mathrm{s}$ denote the probability of plaintiff's victory in the event of a trial and let $J$ represent the resulting judgment. Let $l_{p}$ denote the plaimtiff's hitigation expenses. These expenses may be a contingency fee, in which case $l_{p}$ should be regarded as an expected value, which is already discounted by the probability s. The expected monetary value of a trial to the plaimtiff is sJ $1_{p}$. Let $R_{p}(J, s)$ represent a risk discount, where $R_{p}=0$ for a risk neutral plaintiff and $R_{p}>0$ for a risk-averse plaintiff. The expected value of a trial to the plamtiff is thus $\left(J, s, l_{p}\right)=s J-R_{p}(J, s)-l_{p}$. Similarly, the expected cost of trial to the defendant is $\left(J, s, 1_{d}\right)=s J+R_{d}(J, s)+1_{d}$. An out of court settleinent eliminates the risk of trial and litigation costs, but imposes its own negotiation costs on the parties, denoted $n_{p}$ and $n_{d}$. Thus the surplus froin settling out of court is $R_{p}+R_{d}+l_{p}+l_{d}-n_{p}-n_{d}$. A "(Nash) reasonable" distribution of the surplus is an equal spht by definition.

Proposition: Assume that plaintiff and defendant are symmetrical with respect to transaction costs $\left(l=l_{p}=l_{d}\right.$, and $\left.n=n_{p}=n_{d}\right)$ and risk aversion $\left(R_{p}=R_{d}\right)$. A reasonable settleinent equals the expected judgment.

Proof: Plamtiff receives his threat point, which is his expected net payoff froin trial, plus half the surplus, or [sJ $\left.-\mathbf{R}_{p}-1_{p}\right]+1 / 2\left[R_{p}+R_{d}+1_{p}+l_{d}\right.$ $\left.-n_{p}-n_{d}\right]=s J-n$ by syminetry assumption. Defendant also receives his threat value, plus half the surplus, so he pays the expected net cost of trial to him less half the surplus: $\left[\mathbf{s J}+\mathbf{R}_{\mathbf{d}}+1_{d}\right]-1 / 2\left[\mathbf{R}_{\mathrm{p}}+\mathbf{R}_{\mathbf{d}}+1_{\mathrm{p}}+\mathbf{l}_{\mathbf{d}}-\mathbf{n}_{\mathrm{p}}-\right.$ $\left.n_{d}\right]=s J-n$. Thus defendant pays settlement of sJ to plaintiff and each one pays $n$ in transaction costs. Q.E.D.

Assume that the parties bargain in the inarket for UTCs under the assumption that in the absence of an agreement there will be a reasonable settleinent of disputes as accidents arise. The transaction costs of bargaining are denoted $m_{p}$ and $m_{d}$. Accidents occur with probability $q$. Thus the expected value to the plaimtiff of settlement $\mathrm{sJ}$ with probability $q$ and transaction cost $N p$ is given by $V\left(s J, q, n_{p}\right)=q s J-R_{p}(s J, q)-q n_{p}$. Here $R_{p}=0$ if the accident is wealth neutral. $R_{p}>0$ if the accident is wealth impacting and the plamtiff has perfect first-party insurance. $R_{p}<0$ if the accident is wealth impactimg and the plaintiff has no insurance. Similarly, the corre- 
sponding cost for defendants is given by $C\left(s J, q, n_{d}\right)=q s J+R_{d}(s J, q)+q n_{d}$. Where $R_{p}=0$ if the defendant is risk neutral and $R_{d}>0$ if the defendant is risk adverse. The sale of UTCs eliminates both the risk $R_{p}$ and $R_{d}$, and the transaction $\operatorname{cost} n_{p}$ and $n_{d}$, although the market for UTCs has transaction costs $m_{p}$ and $m_{d}$. Thus the surplus equal $R_{p}+R_{d}+q n_{p}+q n_{d}-m_{p}-$ $\mathrm{m}_{\mathrm{d}}$.

Proposition: Assume the potential plaintiff and potential defendant are symmetrical with respect to transaction costs $\left(l=l_{p}=l_{d}, n=n_{p}=n_{d}, m=m_{p}=m_{d}\right)$ and risk aversion $\left(R_{p}=R_{d}\right)$. A reasonable price for UTCs equals the expected judgment qsJ.

Proof: Plaintiff receives his expected value of settlement plus half the surplus from the bargain: $\left[q s J-R_{p}-q n_{p}\right]+1 / 2\left[R_{p}+R_{d}+q_{p}+q n_{d}-m_{p}-\right.$ $\left.\mathrm{m}_{\mathrm{d}}\right]=\mathrm{qsJ}-\mathrm{m}$, by the symmetry assumptions. Defendant pays his expected cost of settlement plus half the surplus from the bargain: [qsJ $\left.\mathbf{R}_{\mathrm{d}}-\mathrm{qn}_{\mathrm{d}}\right]+1 / 2\left[\mathbf{R}_{\mathrm{p}}+\mathbf{R}_{\mathrm{d}}+\mathrm{qn}_{\mathrm{p}}+\mathrm{qn}_{\mathrm{d}}-\mathrm{m}_{\mathrm{p}}-\mathrm{m}_{\mathrm{d}}\right]=\mathrm{qS} \mathrm{J}+\mathrm{m}$ by symmetry. Thus potential defendant pays qsJ to potential plaintiff for UTCs and each one pays his own transaction costs. Q.E.D.

Suppose that imjurers expose victims to accidents that cause harm whose monetary value is $f$ (for "full compensation") with probability qs. The probability can be reduced by imjurers expenditure $x$ on precaution, according to the functions $q=q(x)$, where $q^{\prime}<0, q^{\prime \prime}>0$. The cost of the risk of accidents and precaution against it is $q(x) s f-R_{p}(f, q s)+x$. The social costs of accidents also include transaction costs. The social costs of accidents with a market for UTCs can thus be written $S C=q(x) s f-R_{p}(f, q s)+x+m_{p}$ $+\mathrm{m}_{\mathrm{d}}$.

Proposition: Assume the potential plaintiff and potential defendant are symmetrical with respect to transaction costs and risk aversion. If courts would set damages equal to the monetary value $f$ of the external harm (full compensation), then a market for UTCs with prices set by reasonable bargaining will result in socially efficient precaution by imjurers.

Proof: The potential injurer minimizes his private costs, which equals the cost of precaution plus the price of UTCs plus transaction costs of bargainmg. The "reasonableness" assumption imphes that the price of UTCs is qsJ. Hence the injurer solves

$$
\min _{x} x+q(x) s J+m_{d}
$$

$J=f$ by assumption. The term $m_{d}$ is constant with respect to $x$. Risk neutrality is achieved by the market for UTCs and first party insurance, so $R_{p}=$ 0 . Hence the solutions to the defendant's problem is the same as min SC. Q.E.D. 
HeinOnline -- 75 Va. L. Rev. 4121989 